\title{
Disaster Information Media in ASEAN Countries: A Paired Comparison Method
}

\author{
MUHAMMAD YUDHI REZALDI \\ RABIAH ABDUL KADIR \\ MOHAMAD TAHA IJAB \\ AZLINA AHMAD \\ Universiti Kebangsaan Malaysia
}

\begin{abstract}
The media, as a tool for creating awareness and educating the community, plays an important role in conveying information about natural disasters. Numerous types of information media can be used at present. However, the most widely used media type, the delivery stages and the role of media in disaster management remain under researched. This study performs a literature review of various information media for natural disasters used in ten Association of Southeast Asian Nations (ASEAN) countries as a reference for creating disaster information media, which will be improved in future research. Information is obtained by reviewing 79 papers. Media information analysis is conducted using the paired comparison method. The components used for comparison cover media types, delivery phase and role in disaster management. Results show that the media used in ASEAN countries are similar: print media (e.g. brochures, posters, and newspapers), and electronic media (e.g. radio, television, Internet and modelling). The results of the analysis also indicate that the most commonly used disaster information media are electronic media, which deliver information during a disaster to convey information on events and losses incurred. Disaster simulation modelling, including evacuation routes and rescue efforts, is the information media that should be more widely used in the future. Information should be disseminated before a disaster occurs, very important apply situational crisis communication theory to an institution of disaster management in making the right decisions, strategic, and useful. Thereby rendering it useful in reducing the loss of life and damage to infrastructure caused by a disaster.
\end{abstract}

Keywords: Disaster information media, types of media, stage of delivery, roles of media, ASEAN countries.

\section{INTRODUCTION}

Natural disasters are unexpected natural events that threaten the functioning and security of people given that they can cause loss of life and damage to materials, such as buildings, plants, and animals (Xu et al., 2016). The media plays an important role in dealing with natural disasters by conveying information and raising the awareness of people living in disasterprone areas (Iqbal et al., 2014; Zhang et al., 2016). Disaster information media are important sources of information before a disaster occurs in an effort to build relationships between disaster managers and the public, given that educating and motivating people to be responsible during disasters are nearly impossible (Venter, 2016).

This research aims to analyse the natural disaster information media used in the Association of Southeast Asian Nations (ASEAN) countries based on a literature review. The objective of this study is to identify the type of disaster information media used in ASEAN countries, the delivery time and the role of media in its delivery. Then are compared by applying the paired comparison method (Westgard, 2009). This study will summarise available media information and the most widely used by ASEAN countries at present. The conclusion of this analysis will be a reference for consideration in creating and delivering 
disaster information media in the future because the delivery of good information through the right disaster information media will save numerous lives and reduce material damage caused by disasters.

Each country in ASEAN has a disaster management institution, one strategy that is used for preparation, response, recovery, and mitigation of natural disasters in delivering disaster information media, i.e. print and electronic media. This paper analyses which types of media are most widely used and the role of each media in conveying information on natural disasters. Also, it analyses how the stages of delivering the right media to be be used in order to be able to reduce the number of victims caused by natural disasters (Ahmad\& Lateh, 2016; Sayama et al., 2017). Ultimately, this paper will conduct a pairwise comparison to identify the measures implemented by ASEAN countries devastated by disasters.

\section{METHODOLOGY}

The methodology in this research, starting with a literature review, as shown in Figure 1 . The process is collecting literature sources, filtering the literature and then analysing and comparing the results. A clarification discussion of media groupings is conducted to determine which natural disaster information media are used in ASEAN countries. Subsequently, an assessment of how to use the media and the role of the media is performed to identify the most used media type, which can be utilised for further comparison among ASEAN countries.

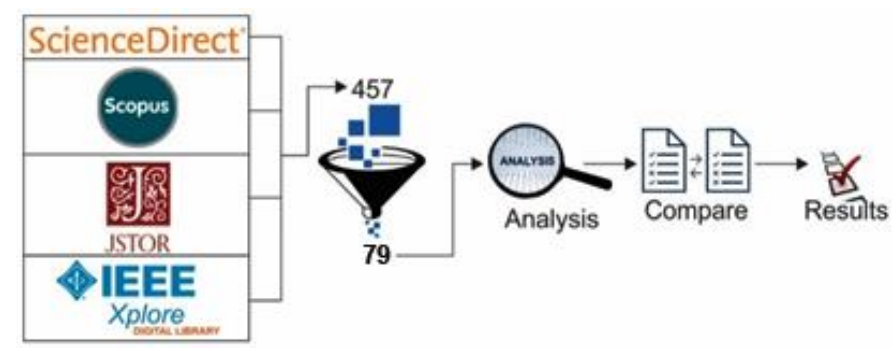

Figure 1: Flow of the review paper of disaster information media

\section{a. Process of Literature Review}

Firstly, the authors search for articles related to themes raised by using Internet search engines, such as ScienceDirect, Scopus, JSTOR and IEEE Xplore Digital Library. The keywords used are ASEAN disaster information media, disaster information media from each ASEAN country (e.g. Indonesia, Malaysia and Singapore), the role of disaster information media, the type of disaster information media, the stages of disaster information delivery and other keywords that are required in this review literature. The articles sought are in English, Malay and Indonesian language, with the year of publication between 2003-2019.

The first phase managed to obtain 457 titles from journals, proceedings, books and articles on websites, which review disaster information media. Then, the authors conducted further screening, and only 79 papers are considered to be in accordance with the theme, i.e. those that specifically discuss the type of media, delivery stages and role of disaster information media. Therefore, these papers can be used as materials in the analysis and comparisons. The review process in this work is explained further in the next paragraph. 


\section{b. Paired Comparison Method}

Disaster information media are analysed in this research by using the paired comparison method to find differences among several objects. If the comparison results show only a slight variation, then the compared objects are considered similar; however, if the variation is considerable, then the objects being compared are regarded as different. The object with a higher value is considered superior (Miranda, 2002; Tsukida \& Gupta, 2011; Ock et al., 2016).

\section{LITERATURE REVIEW}

This section will discuss the definition of disaster information media, types of disaster information media, stages of information delivery, roles of disaster information media, situational crisis communication theory, and also studying institutions of disaster management in each ASEAN country, to find out what disaster information media have been used and how they are applied.

\section{a. Disaster Information Media}

Disaster information media play an important role in spreading information about disaster management. Disaster information is effectively and efficiently delivered to the community due to the development of technology. Through these media, communities become aware of disaster hazards and can coordinate fundraising for disaster victims (Ragini et al., 2017; Anson et al., 2017). The function of disaster information media is to provide information, educate and empower communities with relevant knowledge by guiding them in planning appropriate actions and policies for reducing the impact of disaster events. The media have considerable power to influence public opinion, nationally and globally, because it is widely available as public information (Zhou et al., 2018). The media can guide communities about their vulnerability and increase their capacity to cope with disasters; some media types have been used to convey disaster information (Callaghan, 2016; Landwehr et al., 2016).

\section{b. Types of Disaster Information Media}

The media comprise an integral part of disaster risk management. Radio, television and the Internet are three of the most efficient methods for transmitting knowledge and information on a large scale, i.e. information can reach large groups of people from different fields (Cheng et al., 2015; Fernandez \& Shaw, 2016). Decision makers must understand how to interact well with media because media are divided into print and electronic as shown in Figure 2. Different media types are also grouped based on delivery time.

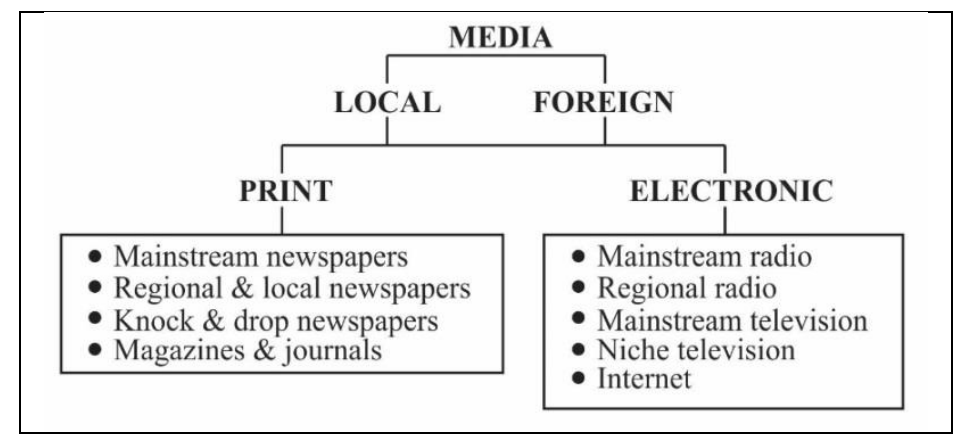

Figure 2: Media types in the implementation of disaster management (Venter, 2016) 


\section{c. Stages of Information Delivery}

In terms of the process, disaster information media are divided into three stages, namely, before, during and after a disaster, as shown in Figure 3.

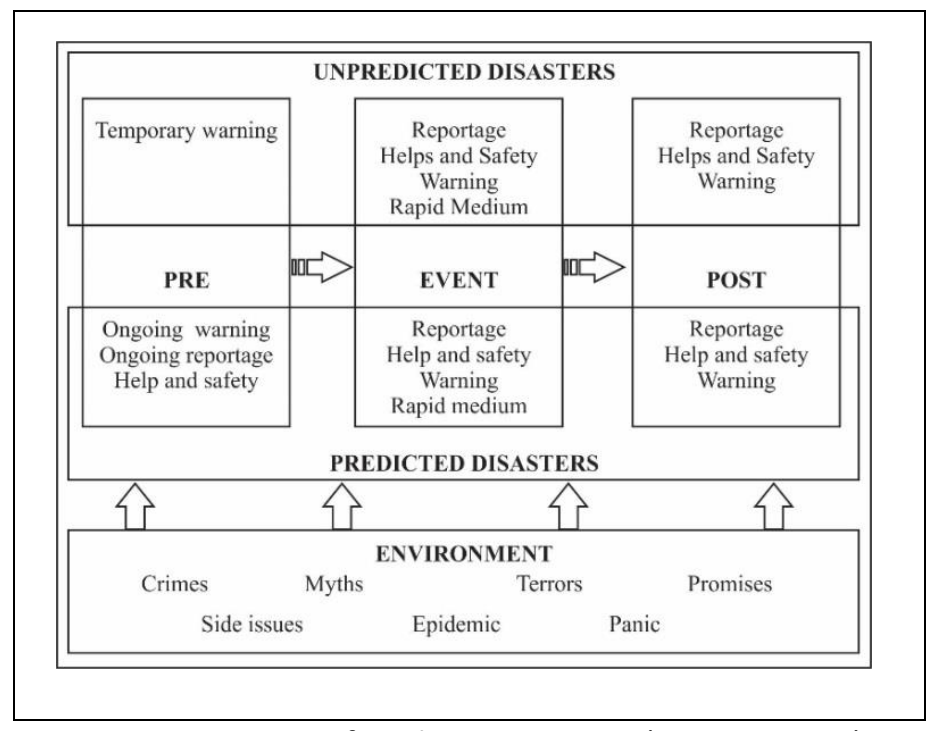

Figure 3: Position of media engagement (Nunung, 2008)

- Before a disaster occurs (pre). The role of the media in this stage is to convey information on the importance of disaster risk reduction and awareness and on making the right decisions to avoid disasters in the future. During this stage, the media promote disaster awareness and mitigation in the following forms: (i) source analysis and risk patterns; (ii) public information, by providing information about disaster risk in a country to build awareness of various disaster hazards; (iii) early warning, by presenting a scientific prediction of dangers through radio, television, and newspapers; (iv) information preparation, by disseminating information and early warning about preventive and security measures and ( $v$ ) encouraging community participation.

- $\quad$ During a disaster (event). The media shall provide information on early warning and emergency operations and broadcast mitigation information through a multimedia service. They should also coordinate with local authorities to receive information on risks and strategies for disaster preparedness, particularly on community awareness. During this time, the media serve to convey information to save as many lives as possible and to avoid the risk of secondary loss. During emergency situations, the media can serve to (i) inform people in a timely and factual manner, (ii) advise the public on the actions that should be taken, (iii) communicate actions that have been conducted by authorities and volunteers, (iv) deliver messages about the safety of people affected by the disaster and ( $v$ ) facilitate communication between survivors and their families or friends from other regions or countries worldwide.

- $\quad$ After the disaster (post). Information rehabilitation, reconstruction of damaged infrastructure and environment and loss of socioeconomic structure and livelihood will be the focus during this stage. An important step in this phase is to integrate disaster risk reduction into the rehabilitation and reconstruction processes to reduce 
future risks (Nunung, 2008). The media can (i) communicate the rehabilitation and reconstruction plans and (ii) influence communities to integrate risk reduction and mitigation into these plans (Disaster Risk Reduction in Lao PDR, 2016; Keur et al., 2016; Jun \& Lihong, 2017). Disaster information media are also categorised by roles.

\section{d. Roles of Disaster Information Media}

On the whole, the disaster information media has several important roles, namely: (a) early preparation, which involves educating the community about various components of a disaster, regardless of the reports and plans to address the problem; (b) response, which comprises directly influencing the affected area, projecting the core needs of the community and informing the affected people where they can get assistance; (c) recovery, which concerns the accountability of aid use, lessons to offer, success stories in rescue efforts and further recovery stages, such as material recovery and (d) mitigation, which consists of reporting and developing improved policies and agenda, managing disaster connectivity with climate change and prioritising discussions on topics (e.g. water, construction, food security, health and livelihood) (Disaster Risk Reduction in Lao PDR, 2016; Silvestri, 2017; Matthews, 2017).

\section{e. Situational Crisis Communication Theory}

For analysis, the disaster information media will also use the situational crisis communication theory which was stated by $\mathrm{W}$. Timothy Coombs, which covers the following guidelines:

- $\quad$ Crisis response strategy guidelines from situational crisis communication theory : (1) Only deliver information about a crisis that has currently occurred. (2) Use the victims as respondents to natural disasters that have happened. (3) Reducing crisis response strategies coupled with similar crisis events that have occurred in the past, along with their reputation of previous negative relationships. (4) Reducing crisis response strategies for crises with low responsibility attribution (accident crises). (5) Rebuilding a crisis response strategy and adding to the reputation of the previous negative relationships. (6) Rebuilding crisis response strategies for crises with a strong attribution of crisis responsibility (preventable crises). (7) Using posture crisis as rejection crisis strategies. (8) Must be consistent in developing crisis response strategies (Coombs, 2007; Kriyantono \& Mckenna, 2019).

- In doing a primary response to the crisis, situational crisis communication theory divides it into three parts, namely: (1) The victim cluster, which is a natural disaster event; in this type, the institution of disaster management is also as a victim. (2) The accidental cluster, which is an accident resulting from technical errors, a technology or equipment failure causing an industrial accident. (3) The intentional cluster, an accident caused by human error, which is also considered as an intentional mistake (Coombs, 2007; Kriyantono \& Mckenna, 2019).

- In making a primary response to a situational crisis, the situational crisis communication theory divides it into three parts, namely : (1) Primary crisis response strategies, by denying or rejecting, by making a statement that there is no crisis that has happened. (2) Primary crisis response strategies, justifying that a crisis has 
happened and some actions must be done to reduce the risks posed by the crisis. (3) Rebuilding crisis response strategies, making a statement of apology and taking full responsibility for the crisis, then rebuilding the damage and providing compensation to the victim. In this strategy, it is also necessary to be informed that institutions of disaster management are part of the victims, and need to be reminded of the good past work done by them (Coombs, 2007; Kriyantono \& Mckenna, 2019).

\section{f. Institutions Responsible for Disasters Management and Disaster Information Media in ASEAN Countries}

The types of disaster information media used in ASEAN countries, the roles of the media and how to use the media are based on the results of the literature review. The various types of disaster information media are grouped according to Venter's theory (2016) (Figure 2): (1) printed media, such as newspapers, brochures, booklets, posters, catalogues and outdoor media (e.g. sign system, flag and Baliho) and (2) electronic media, such as radio and television (live reports, movies, animation, advertising), Internet and smartphones (websites, applications, social media, movies, animation, advertising, bulletins and short message service or SMS) and modelling (simulations, disaster maps and early warning).

\section{- Indonesia}

The National Disaster Management Authority (BNPB) is a government agency that is responsible for handling natural disasters and for educating and building public awareness regarding disasters. The strategy used in dealing with disasters is community-based disaster risk reduction in a community-organised form. Disaster information media are used before, during and after a disaster. Considerable efforts are exerted to prevent, reduce, avoid and recover from the impacts of disasters. The concept of disaster mitigation and training information is also designed (Adila et al., 2017; Carley et al., 2016).

The disaster information media commonly used in Indonesia are as follows: (1) disaster information through pamphlets, booklets and other print media; (2) social media (Facebook, Twitter, Instagram, YouTube, BBM and WhatsApp); (3) websites; (4) television; (5) radio; (6) newspapers; (7) mobile phones; (8) real-time disaster maps; (9) sign system; (10) simulations using ANUGA Hydro software and (11) hydrology simulations (Texier, 2008; Arifianto \& Virhani, 2009; Nugroho, 2017; Parwanto \& Oyama, 2014).

\section{- Malaysia}

The National Disaster Relief Centre (NDCC) and the National Disaster Relief Agency (NADMA) are the organisations responsible for managing all natural hazard operation centres in Malaysia. Their primary objective is to build public awareness through a national approach of fostering and enhancing risk-conscious communities and to encourage community involvement in prevention, mitigation, preparedness, response and recovery strategies (Dorasamy et al., 2007).

A spatial decision support system, which is a technology in flood disaster management that combines the ability in the field of dialogue among system components, data acquisition, storage, retrieval, data modelling and manipulation, has been applied in Malaysia (Rezaldi et al., 2017), has also conducted a campaign to build communities that can understand the vulnerabilities, strategies, activities and roles that can be adopted in managing flood risks (Billa et al., 2006). In general, the disaster information media in Malaysia are as follows: (1) newspapers; (2) magazines; (3) flyers; (4) television; (5) radio; (6) websites; (7) social media 
(WhatsApp, Facebook and Twitter); (8) alarm; (9) simulations using XPSWMM, geographic information systems (GIS) and T-Copula; (10) interactive CD and (11) mobile phones (Ahmad \& Lateh, 2016; Chong et al., 2014; Kia et al., 2012).

\section{- Brunei}

The National Disaster Mitigation Centre (NDMC) plays a crucial role in the safety and wellbeing of communities; it covers all aspects of disaster management, prevention, handling, recovery, policy and practice (Brunei Darussalam Presentation, 2015). Information on natural disasters in Brunei includes prevention, mitigation, preparedness, creation of resilient communities by developing community awareness of disaster risks and the ability to manage emergencies. NDMC also creates policies, strategies and practices for disaster response and recovery. Its approach includes an early warning, flood forecasting, real-time flood information through 34 radio transmitters of hydrological readers (telemetric units) and mapping of disaster-prone areas.

Moreover, NDMC organises essay writing competitions, workshops on the role of the media in disaster and non-disaster situations, disaster awareness quizzes on radio, disaster awareness messages on television and the publication of articles about disaster management in Brunei Darussalam (Ndah \& Odihi, 2017; Tan et al., 2017). The disaster information media used by Brunei Darussalam are as follows: (1) websites, (2) social media, (3) simulations (hydrology, disaster maps and early warning), (4) newspapers, (5) posters, (6) booklets, (7) radio, (8) television and (9) mobile phones (Baharudin et al., 2017).

\section{- $\quad$ Singapore}

The Singapore Civil Defence Force (SCDF) is the central body responsible for the provision of emergency services in Singapore during safety and emergency. It implements strategies for sharing information on natural disasters and protection measures and for communicating disaster management efforts. Disaster information is communicated to communities through various disaster information media before, during and after a disaster. SCDF also builds good relationships with the media to raise public awareness of disaster mitigation efforts (Chan et al., 2012).

The efforts and contents of disaster information in Singapore are as follows: rainfall data for the occurrence of floods; simulation of 1D or 2D hydraulic profiles and channel flows for flood events; flood maps and speed fields to inform communities of the affected locations and the severity of each flood event through radio broadcasts; real-time updates on Facebook, Twitter, websites, press releases, SMS and phone apps and presentations in Marina Barrage Sustainable Singapore Gallery, NEWater Visitor Centre and ENV Gallery, for the effective communication of drainage and flood management. In addition, Singapore provides a 24-hour hot drainage channel to solve problems and backlashes on drainage and flood issues and to distribute pamphlets, information packages, signatures and mobile exhibitions to increase public awareness of and readiness for flood (Li et al., 2018; Liu \& Wang, 2018; Kibanov et al., 2017). Overall, the disaster information media used in Singapore are as follows: (1) radio, (2) websites, (3) social media, (4) mobile phones, (5) newspapers, (6) flyers, (7) booklets, (8) simulations (hydraulic, hydrodynamic and disaster maps) and, (9) television (Goh et al., 2015). 


\section{- $\quad$ Thailand}

The Department for Disaster Management and Response (DDPM) is assigned to gain an advantage in securing the welfare of the people by meeting international standards. Through the Ministry of Information and Communication Technology, DDPM is responsible for preparing assistance, standby communication and communication systems and personnel that maintain communication during disaster events.

DDPM receives information and communication through the Centre for Excellence in Disaster Management and Humanitarian Assistance (CFE-DMHA). Most of the information is disseminated through the following media: (1) social media, (2) websites, (3) newspapers, (4) posters, (5) booklets, (6) television, (7) radio, (8) modelling (hydrodynamic simulations and rain pools formed from rain) and (9) mobile phones (Chongkolrattanaporn, 2013; Kaewkitipong et al., 2012; Sayama et al., 2017).

\section{- Philippines}

The National Disaster Risk Reduction and Management Council (NDRRMC) is the board responsible for the protection and welfare of communities during disasters or emergencies in the Philippines (ABC International Development, 2017).

The Philippine government has exerted various efforts in the face of natural disasters. For example, emergency regulations have been formulated and standard operating procedures and monitoring and warning systems have been developed. A disaster preparedness education centre equipped with an audiovisual/training room has been established. A small disaster management museum has been set up, and a disaster management library for children and adults has been opened. Disaster management manuals with instructions on how to prepare people for emergencies and what to do during emergencies are published. SMS and early warning systems are also used. A mix of scheduled bulletins and traditional press releases, with multiple uses of social media, is provided. A flood map, which is 2D flood simulation using a grid model, and a 2D hydrodynamic model are utilised to find the location of evacuation sites using a multi-agent system model.

The disaster information media used in the Philippines are as follows: (1) television, (2) radio, (3) websites, (4) newspapers, (5) posters, (6) flyers, (7) modelling (grid, hydrology, disaster maps and a multi-agent system), (8) social media, (9) mobile phones and (10) a disaster management museum (Asian Disaster Preparedness Centre, 2008; NDRRMC, 2012; Vieweg et al., 2014).

\section{- Vietnam}

The General Department of Disaster Prevention and Control, which is under the Ministry of Agriculture and Rural Development (MARD), coordinates natural disasters, mobilises social resources and ensures the participation of all communities in disaster prevention and control. The department is in charge of promoting international cooperation with other countries for effective disaster management and prevention (Tuan \& Bui, 2012).

The Vietnamese government has exerted various efforts in disaster preparedness by establishing club information; providing education, communication, simulation exercises and awareness; upgrading easy access; formulating laws; creating visual information in the community; campaigning in schools, known as 'Schools of Son Tinh', with educational programs, tsunami and disaster drills and awareness-raising activities and conducting numerical simulations of a tsunami. For the delivery of information about the environment, Internet-based information media through Facebook have become the primary choice for the 
educated youth of Vietnam, as it has 93 million users and has never been banned in the country (Borton \& Tho, 2017).

Disaster information is conveyed through (1) modelling (numerical simulations and early warning systems), (2) newspapers, (3) booklets, (4) websites, (5) social media, (6) television, (7) radio and, (8) mobile phones (Dung et al., 2012; Takagi et al., 2014; Tuan \& Bui, 2012).

\section{- Myanmar}

The National Disaster Management Committee (NDMC) is part of the central government's effort to coordinate and support disaster preparedness, relief and management at the national level (NNDMCR, 2015). One of its strategies for implementing disaster mitigation is adopting the Hydrologic Modelling System of the Hydrologic Engineering Centre (HEC-HMS) for hydrological modelling, which can assess and analyse parameters and visualisations for flood disasters (Zin et al., 2015).

NDMC applies several approaches, such as establishing policies and plans for national and regional management, which are developed by the government; providing disaster information through websites, various academics, artists, newspapers, news and video on television and publishing information on various social media, such as Facebook, Instagram and WhatsApp (Linda, 2017). NDMC has also developed a disaster information module with posters as a teaching tool for disaster-themed activities, in conjunction with radio broadcast (Rural Settings, 2011).

The disaster information media in Myanmar consist of the following: (1) bulletins of flood information; (2) maps of flooding information; (3) HEC-HMS hydrological modelling, i.e. HEC-River Analysis System (RAS) is used in hydrological and hydraulic modelling to measure flood depth; (4) social media (Facebook and Instagram); (5) newspaper articles; (6) radio and television newscasts; (7) websites; (8) booklets; (9) posters and, (10) mobile phones (Aye et al., 2017).

\section{- Laos}

The National Committee on Disaster Prevention and Control (NCDPC) is responsible for establishing disaster risk management and management plans, building community awareness on disaster response and developing disaster preparedness. NCDPC organises its program into three parts: prior to a disaster to provide early warning and build disaster preparedness, during a disaster by monitoring damage and providing assistance and after a disaster with recovery and reconstruction (Disaster Recovery Framework, 2014). NCDPC delivers and disseminates flood disaster and spatial data from GIS. In addition, it firstly assesses the disaster environment before collecting information by answering the following questions: Where did the data come from? When will the data be available? Are the data sources reliable? In what form is the information required? Is the information relevant to the destination? Is the information accurate, clear and appropriate? (Bourgoin et al., 2012).

On the basis of the data that have been prepared through various questions, Laos authorities disseminate disaster information through (1) radio, (2) television, (3) mobile phones, (4) social media, (5) websites, (6) modelling (statistics, hydrology and early warning), (7) newspapers, (8) flags, (9) signboards and, (10) alarms (Plate, 2007; Coppola, 2011; Lintner, 2003). 


\section{- Cambodia}

The National Committee for Disaster Management (NCDM) is an institution authorised by the Cambodian government for disaster management and handling (CFE-DMHA, 2014). The Cambodian government continuously cooperates with UNICEF by publishing study reports, booklets and handbooks to provide disaster information for children and women (Cambodia UNICEF, 2017). It also sets up alert boards that provide information about high-level flooding and that predict future floods. In an effort to influence the entire community in Mekong Valley, the government transmits information online and broadcasts it through radio. Disaster simulation models have also been used in Cambodia based on hydrometeorological data (Mekong River Commission, 2011).

Disaster information in Cambodia is disseminated through the following media: (1) disaster maps, (2) hydrological modelling (2D simulations), (3) Baliho to provide the water level, (4) social media, (5) radio, (6) television, (7) booklets, (8) newspapers, (9) websites and, (10) mobile phones (Burnett et al., 2017; Thanh et al., 2017).

\section{ANALYSIS AND PAIRED COMPARISON OF DISASTER INFORMATION MEDIA IN ASEAN COUNTRIES}

In analysis, a paired comparison is carried out to explore in-depth whether there are similarities or differences in conveying disaster information media in ASEAN countries so that in the end it can conclude the type of media, stage of delivery, and what is the role of that media. Finally can recommend disaster information media that is most recommended for further development. This comparison is divided into three parts: 1. Media type (Venter, 2016), 2. Stages of information media delivery (Nunung, 2008) and 3. The role of the media (Disaster Risk Reduction in Lao PDR, 2016), as shown in Table 1, Table 2 and Table 3.

Table 1: Comparison of media types

\begin{tabular}{|c|c|c|}
\hline \multirow{2}{*}{$\begin{array}{l}\text { ASEAN } \\
\text { country }\end{array}$} & \multicolumn{2}{|l|}{ Media type } \\
\hline & Electronic & Print \\
\hline Indonesia & $\begin{array}{l}\text { Social media. Websites. Television. Radio. } \\
\text { Mobile phones. Disaster maps. Simulations. }\end{array}$ & $\begin{array}{l}\text { Pamphlets. } \\
\text { Booklets. } \\
\text { Newspapers. Sign } \\
\text { systems. }\end{array}$ \\
\hline Malaysia & $\begin{array}{l}\text { Television. Radio. Websites. Social media. } \\
\text { Alarms. Mobile phones. Simulations. Interactive } \\
\text { CD. }\end{array}$ & $\begin{array}{l}\text { Newspaper. } \\
\text { Magazines. Flyers. }\end{array}$ \\
\hline Brunei & $\begin{array}{l}\text { Websites. Social media. Simulations. Radio. } \\
\text { Television. Mobile phones. }\end{array}$ & $\begin{array}{c}\text { Newspapers. } \\
\text { Posters. Booklets. }\end{array}$ \\
\hline Singapore & $\begin{array}{l}\text { Radio. Websites. Social media. Mobile phones. } \\
\text { Simulations. Television. }\end{array}$ & $\begin{array}{l}\text { Newspapers. Flyers. } \\
\text { Booklets. }\end{array}$ \\
\hline Thailand & $\begin{array}{c}\text { Social media. Websites. Television. Radio. } \\
\text { Modelling. Mobile phones. }\end{array}$ & $\begin{array}{l}\text { Newspapers. } \\
\text { Posters. Booklets. }\end{array}$ \\
\hline Philippines & $\begin{array}{l}\text { Television. Radio. Websites. Modelling. Social } \\
\text { media. Mobile phones. }\end{array}$ & $\begin{array}{l}\text { Newspapers. } \\
\text { Posters. Flyers. } \\
\text { Disaster } \\
\text { management } \\
\text { museum. }\end{array}$ \\
\hline Vietnam & $\begin{array}{l}\text { Modelling. Websites. Social media. Television. } \\
\text { Radio. Mobile phones. }\end{array}$ & $\begin{array}{l}\text { Newspapers. } \\
\text { Booklets. }\end{array}$ \\
\hline Myanmar & $\begin{array}{l}\text { Disaster maps. Modelling. Social media. Video. } \\
\text { Radio. Television. Websites. Mobile phones. }\end{array}$ & $\begin{array}{l}\text { Bulletins. } \\
\text { Newspapers. } \\
\text { Booklets. Posters. }\end{array}$ \\
\hline
\end{tabular}




\begin{tabular}{ccc}
\hline Laos & Radio. Television. Mobile phones. Social media. & Newspapers. \\
& Websites. Modelling. Alarms. & Signboards. Flags. \\
Cambodia & Disaster maps. Hydrological modelling. 2D & Baliho to provide \\
& simulations. Mobile phones. Social media. & water level. \\
& Radio. Television. Websites. & Booklets. \\
& & Newspapers. \\
\hline
\end{tabular}

Sources: $A B C$ International Development, 2017; Arifianto \& Virhani, 2009; Brunei Darussalam Presentation, 2015; Burnett et al., 2017; Cambodia UNICEF, 2017; CFE-DMHA, 2014; Chan et al., 2012; Chongkolrattanaporn, 2013; Coppola, 2011; Disaster Recovery Framework, 2014; Goh et al., 2015; Kaewkitipong et al., 2012; Nugroho, 2017; Thanh et al., 2017.

Table 2: Comparison of stages of information media delivery

\begin{tabular}{|c|c|c|c|}
\hline \multirow{2}{*}{$\begin{array}{l}\text { ASEAN } \\
\text { country }\end{array}$} & \multicolumn{3}{|c|}{ Stage of information media delivery } \\
\hline & Pre & Event & Post \\
\hline Indonesia & $\begin{array}{l}\text { Pamphlets. Booklets. } \\
\text { Social media. } \\
\text { Websites. Television. Sign } \\
\text { systems. Simulations. }\end{array}$ & $\begin{array}{l}\text { Social media. Websites. } \\
\text { Television. Radio. } \\
\text { Newspapers. Mobile phones. } \\
\text { Disaster maps. }\end{array}$ & $\begin{array}{c}\text { Social media. Websites. } \\
\text { Television. Radio. } \\
\text { Newspapers. }\end{array}$ \\
\hline Malaysia & $\begin{array}{c}\text { Flyers. Social media. } \\
\text { Websites. Television. } \\
\text { Simulations. Interactive } \\
\text { CD. }\end{array}$ & $\begin{array}{c}\text { Newspapers. Television. } \\
\text { Radio. Websites. } \\
\text { Social media. Alarms. Mobile } \\
\text { phones. }\end{array}$ & $\begin{array}{c}\text { Newspapers. Television. } \\
\text { Radio. Websites. } \\
\text { Social media. }\end{array}$ \\
\hline Brunei & $\begin{array}{c}\text { Websites. Social media. } \\
\text { Simulations. Posters. } \\
\text { Booklets. }\end{array}$ & $\begin{array}{c}\text { Websites. Social media. } \\
\text { Newspapers. Radio. } \\
\text { Television. Mobile phones. }\end{array}$ & $\begin{array}{l}\text { Websites. Social media. } \\
\text { Newspapers. Television. }\end{array}$ \\
\hline Singapore & $\begin{array}{l}\text { Websites. Social media. } \\
\text { Flyers. Booklets. } \\
\text { Simulations. }\end{array}$ & $\begin{array}{l}\text { Radio. Websites. Social } \\
\text { media. Mobile phones. } \\
\text { Newspapers. Television }\end{array}$ & $\begin{array}{c}\text { Radio. Websites. Social } \\
\text { media. Newspapers. } \\
\text { Television. }\end{array}$ \\
\hline Thailand & $\begin{array}{c}\text { Social media. } \\
\text { Websites. Poster. } \\
\text { Booklets. Modelling. }\end{array}$ & $\begin{array}{l}\text { Social media. Websites. } \\
\text { Newspapers. Television. } \\
\text { Radio. Mobile phones. }\end{array}$ & $\begin{array}{l}\text { Social media. Websites. } \\
\text { Newspapers. Television. }\end{array}$ \\
\hline Philippines & $\begin{array}{l}\text { Websites. Posters. Flyers. } \\
\text { Modelling. Social media. }\end{array}$ & $\begin{array}{l}\text { Television. Radio. Websites. } \\
\text { Newspapers. Social media. } \\
\text { Mobile phones. }\end{array}$ & $\begin{array}{l}\text { Television. Websites. } \\
\text { Newspaper. Social media. } \\
\text { Disaster management } \\
\text { museum. }\end{array}$ \\
\hline Vietnam & $\begin{array}{c}\text { Modelling. Booklets. } \\
\text { Websites. Social Media. }\end{array}$ & $\begin{array}{l}\text { Newspapers. Websites. } \\
\text { Social media. Television. } \\
\text { Radio. Mobile phones. }\end{array}$ & $\begin{array}{l}\text { Newspapers. Websites. } \\
\text { Social Media. Television. }\end{array}$ \\
\hline Myanmar & $\begin{array}{l}\text { Disaster maps. } \\
\text { Modelling. Social media. } \\
\text { Websites. Booklets. } \\
\text { Posters. }\end{array}$ & $\begin{array}{l}\text { Social media. Newspapers. } \\
\text { Television. Radio. Websites. } \\
\text { Mobile phones. }\end{array}$ & $\begin{array}{l}\text { Bulletins. Social media. } \\
\text { Newspapers. Television. } \\
\text { Radio. Websites. }\end{array}$ \\
\hline Laos & $\begin{array}{l}\text { Social media. Websites. } \\
\text { Modelling. Newspapers. } \\
\text { Signboards. }\end{array}$ & $\begin{array}{l}\text { Radio. Television. Social } \\
\text { media. Websites. } \\
\text { Newspapers. Flags. Alarms. } \\
\text { Mobile phones. }\end{array}$ & $\begin{array}{c}\text { Radio. Television. Social } \\
\text { media. Websites. } \\
\text { Newspapers. }\end{array}$ \\
\hline Cambodia & $\begin{array}{l}\text { Disaster maps. } \\
\text { Modelling. Social media. } \\
\text { Booklets. Websites. }\end{array}$ & $\begin{array}{c}\text { Modelling. Baliho. Social } \\
\text { media. Radio. Television. } \\
\text { Newspapers. Websites. } \\
\text { Mobile phones. }\end{array}$ & $\begin{array}{c}\text { Social media. Radio. } \\
\text { Television. Newspapers. } \\
\text { Websites. }\end{array}$ \\
\hline
\end{tabular}

Sources : Adila et al., 2017; Asian Disaster Preparedness Centre, 2008; Baharudin et al., 2017; Carley et al., 2016; Dorasamy et al., 2007; Kia et al., 2012; Linda, 2017; Li et al., 2018; Mekong River Commission, 2011; NNDMCR, 2015; Parwanto \& Oyama, 2014; Rural Settings, 2011; Takagi et al., 2014; Zin et al., 2015. 
Table 3: Comparison of the roles of media

\begin{tabular}{|c|c|c|c|c|}
\hline \multirow{2}{*}{$\begin{array}{l}\text { ASEAN } \\
\text { country }\end{array}$} & \multicolumn{4}{|c|}{ Roles of media } \\
\hline & Preparation & Response & Recovery & Mitigation \\
\hline Indonesia & $\begin{array}{l}\text { Pamphlets. Booklets. } \\
\text { Websites. Disaster } \\
\text { maps. Sign systems. } \\
\text { Simulations. }\end{array}$ & $\begin{array}{l}\text { Social media. Websites. } \\
\text { Television. Radio. } \\
\text { Newspapers. Mobile } \\
\text { phones. }\end{array}$ & $\begin{array}{l}\text { Social media. } \\
\text { Websites. } \\
\text { Television. } \\
\text { Radio. } \\
\text { Newspapers. }\end{array}$ & $\begin{array}{l}\text { Social media. } \\
\text { Websites. } \\
\text { Television. Radio. } \\
\text { Newspapers. }\end{array}$ \\
\hline Malaysia & $\begin{array}{c}\text { Magazines. Flyers. } \\
\text { Websites. Simulations. } \\
\text { Interactive CD. }\end{array}$ & $\begin{array}{c}\text { Newspapers. } \\
\text { Television. Radio. } \\
\text { Websites. Social media. } \\
\text { Alarms. Mobile phones. }\end{array}$ & $\begin{array}{l}\text { Newspapers. } \\
\text { Television. } \\
\text { Radio. Websites. } \\
\text { Social media. }\end{array}$ & $\begin{array}{l}\text { Newspapers. } \\
\text { Television. } \\
\text { Websites. Social } \\
\text { media. }\end{array}$ \\
\hline Brunei & $\begin{array}{c}\text { Websites. Simulations. } \\
\text { Newspapers. Posters. } \\
\text { Booklets. }\end{array}$ & $\begin{array}{c}\text { Websites. Social media. } \\
\text { Newspapers. Radio. } \\
\text { Television. Mobile } \\
\text { phones. }\end{array}$ & $\begin{array}{l}\text { Websites. Social } \\
\text { media. } \\
\text { Newspapers. } \\
\text { Television. }\end{array}$ & $\begin{array}{c}\text { Websites. Social } \\
\text { media. } \\
\text { Newspapers. } \\
\text { Radio. Television. }\end{array}$ \\
\hline Singapore & $\begin{array}{l}\text { Websites. Newspapers. } \\
\text { Flyers. Booklets. } \\
\text { Simulations. }\end{array}$ & $\begin{array}{c}\text { Radio. Websites. Social } \\
\text { media. Mobile phones. } \\
\text { Newspapers. } \\
\text { Television. }\end{array}$ & $\begin{array}{l}\text { Radio. Websites. } \\
\text { Social media. } \\
\text { Television. }\end{array}$ & $\begin{array}{c}\text { Radio. Websites. } \\
\text { Social media. } \\
\text { Television. }\end{array}$ \\
\hline Thailand & $\begin{array}{c}\text { Websites. Newspapers. } \\
\text { Posters. Booklets. } \\
\text { Modelling. }\end{array}$ & $\begin{array}{c}\text { Social media. Websites. } \\
\text { Newspapers. } \\
\text { Television. Radio. } \\
\text { Mobile phones. }\end{array}$ & $\begin{array}{l}\text { Social media. } \\
\text { Websites. } \\
\text { Newspapers. } \\
\text { Television. } \\
\text { Radio. }\end{array}$ & $\begin{array}{l}\text { Social media. } \\
\text { Websites. } \\
\text { Newspapers. } \\
\text { Television. }\end{array}$ \\
\hline Philippines & $\begin{array}{c}\text { Websites. Newspapers. } \\
\text { Posters. Flyers. } \\
\text { Modelling. }\end{array}$ & $\begin{array}{l}\text { Television. Radio. } \\
\text { Websites. Newspapers. } \\
\text { Social media. Mobile } \\
\text { phones. }\end{array}$ & $\begin{array}{l}\text { Television. } \\
\text { Websites. } \\
\text { Newspapers. } \\
\text { Social media. }\end{array}$ & $\begin{array}{l}\text { Television. Radio. } \\
\text { Newspaper. } \\
\text { Social media. }\end{array}$ \\
\hline Vietnam & $\begin{array}{l}\text { Modelling. } \\
\text { Newspapers. Booklets. } \\
\text { Websites. }\end{array}$ & $\begin{array}{c}\text { Newspapers. Websites. } \\
\text { Social Media. } \\
\text { Television. Radio. } \\
\text { Mobile phones. }\end{array}$ & $\begin{array}{l}\text { Newspapers. } \\
\text { Websites. } \\
\text { Social media. } \\
\text { Television. }\end{array}$ & $\begin{array}{l}\text { Newspapers. } \\
\text { Websites. } \\
\text { Social media. } \\
\text { Television. } \\
\text { Radio. }\end{array}$ \\
\hline Myanmar & $\begin{array}{l}\text { Disaster maps. } \\
\text { Modelling. Websites. } \\
\text { Booklets. Posters. }\end{array}$ & $\begin{array}{c}\text { Social media. } \\
\text { Newspapers. } \\
\text { Television. Radio. } \\
\text { Websites. Mobile } \\
\text { phones. }\end{array}$ & $\begin{array}{l}\text { Social media. } \\
\text { Newspapers. } \\
\text { Television. } \\
\text { Websites. }\end{array}$ & $\begin{array}{c}\text { Disaster maps. } \\
\text { Social media. } \\
\text { Newspapers. } \\
\text { Television. Radio. } \\
\text { Websites. } \\
\text { Booklets. Posters. }\end{array}$ \\
\hline Laos & $\begin{array}{l}\text { Websites. Modelling. } \\
\text { Newspapers. } \\
\text { Signboards. }\end{array}$ & $\begin{array}{l}\text { Radio. Television. } \\
\text { Mobile phones. Social } \\
\text { media. Websites. } \\
\text { Newspapers. Flags. } \\
\text { Signboards. Sirens. }\end{array}$ & $\begin{array}{l}\text { Radio. } \\
\text { Television. Social } \\
\text { media. Websites. } \\
\text { Newspapers. }\end{array}$ & $\begin{array}{l}\text { Television. Social } \\
\text { media. Websites. } \\
\text { Newspapers. }\end{array}$ \\
\hline Cambodia & $\begin{array}{l}\text { Flood maps. } \\
\text { Hydrological modelling. } \\
\text { 2D simulations. } \\
\text { Booklets. Websites. }\end{array}$ & $\begin{array}{l}\text { Baliho to provide water } \\
\text { level. Social media. } \\
\text { Radio. Television. } \\
\text { Newspapers. Websites. } \\
\text { Mobile phones. }\end{array}$ & $\begin{array}{l}\text { Social media. } \\
\text { Radio. } \\
\text { Television. } \\
\text { Newspapers. } \\
\text { Websites. }\end{array}$ & $\begin{array}{c}\text { Flood maps. Social } \\
\text { media. Radio. } \\
\text { Television. } \\
\text { Newspapers. } \\
\text { Websites. }\end{array}$ \\
\hline
\end{tabular}

Sources : Ahmad \& Lateh, 2016; Aye et al., 2017; Borton \& Tho, 2017; Bourgoin et al., 2012; Chong et al., 2014; Dung et al., 2012; Kibanov et al., 2017; Lintner, 2003; Liu \& Wang, 2018; NDRRMC, 2012; Plate, 2007; Sayama et al., 2017; Texier, 2008; Tuan \& Bui, 2012; Vieweg et al., 2014. 
The three phases of paired comparisons at the table above (type of media, stages of information delivery, and role of the media), is calculated by the quantity used so that it can be seen which is the most widely and least used, as seen in table 4.

Table 4: The calculation of quantity type of media, stage of information delivery, and role of the disaster information media

\begin{tabular}{|c|c|c|c|c|c|c|c|c|c|}
\hline \multirow[t]{2}{*}{$\begin{array}{l}\text { ASEAN } \\
\text { country }\end{array}$} & \multicolumn{2}{|c|}{ Type of media } & \multicolumn{3}{|c|}{$\begin{array}{c}\text { Stage of information } \\
\text { delivery }\end{array}$} & \multicolumn{4}{|c|}{ Role of the media } \\
\hline & Electronic & Print & Pre & Event & Post & Preparation & Response & Recovery & Mitigation \\
\hline Indonesia & 7 & 4 & 7 & 8 & 5 & 6 & 6 & 5 & 5 \\
\hline Malaysia & 7 & 3 & 6 & 7 & 5 & 5 & 7 & 5 & 4 \\
\hline Brunei & 5 & 3 & 5 & 6 & 4 & 5 & 6 & 4 & 5 \\
\hline Singapore & 6 & 3 & 5 & 6 & 5 & 5 & 6 & 4 & 4 \\
\hline Thailand & 5 & 3 & 5 & 6 & 4 & 5 & 6 & 5 & 4 \\
\hline Philippines & 5 & 3 & 5 & 6 & 5 & 5 & 6 & 4 & 4 \\
\hline Vietnam & 5 & 2 & 4 & 6 & 4 & 4 & 6 & 4 & 5 \\
\hline Myanmar & 7 & 4 & 6 & 6 & 6 & 5 & 6 & 4 & 8 \\
\hline Laos & 7 & 3 & 5 & 8 & 5 & 4 & 9 & 5 & 4 \\
\hline Cambodia & 6 & 3 & 5 & 8 & 5 & 6 & 6 & 5 & 6 \\
\hline Quantity & 60 & 31 & 53 & 67 & 48 & 50 & 64 & 45 & 49 \\
\hline
\end{tabular}

Results from the calculation of quantity type of media, stage of information delivery, and the role of the disaster information media in table 4 , is created in percentage format as shown in Figure 4.

Figure 4: Percentage paired comparison results of disaster information media used in ASEAN countries

\begin{tabular}{|c|c|c|c|}
\hline \multicolumn{4}{|c|}{ (a) Type of media } \\
\hline \multicolumn{3}{|c|}{$\begin{array}{c}\text { Electronic } \\
66 \%\end{array}$} & $\begin{array}{l}\text { Print } \\
34 \%\end{array}$ \\
\hline \multicolumn{4}{|c|}{ (b) Information delivery } \\
\hline \multicolumn{2}{|l|}{$\begin{array}{l}\text { Even } \\
40 \%\end{array}$} & $\begin{array}{l}\text { Pre } \\
31 \%\end{array}$ & $\begin{array}{l}\text { Post } \\
29 \%\end{array}$ \\
\hline \multicolumn{4}{|c|}{ (c) Role of the media } \\
\hline $\begin{array}{c}\text { Response } \\
31 \%\end{array}$ & $\begin{array}{c}\text { Preparation } \\
24 \%\end{array}$ & $\begin{array}{c}\text { Mitigation } \\
23 \%\end{array}$ & $\begin{array}{c}\text { Recovery } \\
22 \%\end{array}$ \\
\hline
\end{tabular}

Figure 4 shows that:

(a) For the type of disaster information media, electronic media, i.e. using social media, such as Facebook, Twitter, YouTube and WhatsApp, are more dominant (66\%) than print media (34\%).

(b) With regard to the time of delivering information, media are most widely used when disaster happens (even) at $40 \%$, followed by before (pre) a disaster occurs at $31 \%$ and lastly, after a disaster occurs (post) at $29 \%$.

(c) For their role, media are most widely used to deliver information for a response $(31 \%)$, followed by preparation (24\%), mitigation (23\%) and finally, recovery (22\%).

Besides the three analyses that have been carried out previously (types of media, information delivery, and the role of the media), analyses were also conducted using the situational crisis communication theory, results of which showed that to be able to convey 
good crisis information, it is very important to follow the guidelines in building a crisis response strategy that is set out in the situational crisis communication theory. The type of crises discussed in this paper is from the victim cluster, which are natural disaster events, in which institutions of disaster management are also victims. The main response to what must be done according to the primary crisis response strategies first is to make the clear justification that a crisis has happened, and therefore some actions must be taken to reduce the risk posed by the crisis, followed by carrying out the formation of the rebuild crisis response strategies. This is done by making an apology statement and taking full responsibility for the crisis, and then rebuilding the damage caused, and providing compensation to the victims (Coombs, 2007; Kriyantono \& Mckenna, 2019).

\section{RESULTS AND DISCUSSION}

In this part of the results and discussion, we will discuss some of the findings obtained from the literature review, analysis, and paired comparison of disaster information media in ASEAN countries, namely:

a. Data from the results of a paired comparison analysis shows that the most widely used disaster information media by ASEAN countries are electronic media, however, print media are still used but the volume is not as much as the use of electronic media.

b. Very important to know the strengths and weaknesses of each type of media, before deciding which one to use. Electronic media has the strength of being able to convey information directly and quickly, can convey information audio and visual at once, can reach a wider audience, more easily understood by everyone, can be used repeatedly, and able to penetrate the limits of distance, space and time. While the disadvantages of electronic media are that it requires high production costs, very dependent on transmitter waves and signals, requires electricity or batteries, not everyone has electronic equipment, and it is difficult to convey complex or abstract information.

For print media, their strengths are due to the low production costs, more flexible in determining the publication time, can be used for a long time, broad market coverage, and can be read repeatedly. While the weaknesses of print media are that it takes longer to convey information because it requires the production process of printing, only able to convey text and image (visual), short life span to convey information, depends on the good design process, the audience may difficult to understand chaotic design content, and limited distribution coverage is selected areas.

c. Considering the number and type of media information, the media have been used sufficiently in communicating disasters. Nevertheless, why are there many casualties from every disaster event? For example, for the earthquake that occurred in August 2018 on Lombok Island, at least 555 people died, 390,529 people were displaced and at least 80,588 buildings were damaged. An in-depth evaluation is required to answer this question. In summary, the author suggests that the media should be delivered earlier before the disaster occurs as a means of education to enable people to understand disaster signs and what efforts should be exerted in the event of a disaster. 
d. Results of the paired comparison analysis also show that stages of information delivery of disaster information media are the most widely used during a disaster (event). Nevertheless, delivery during a disaster happened does not have an impact in minimizing casualties, but only serves as a response to the disaster event that happened. It would be effective if more disaster information media were created and delivered at a much earlier time before the disaster happened with the early preparation functions, such as by making simulation models, the information signs of a disaster, and to educate the people to the steps that should be taken to save themselves. Finally the efforts to minimize fatalities and material loss due to the disaster.

e. The use of media during a disaster does not seem to help considerably other than to convey damage information, a number of victims and response regarding victim search and rescue. Moreover, the delivery of information after a disaster typically concerns an effort to raise funds, deliver help and report aid distribution. Awareness of the information conveyed through social media and unofficial websites are necessary because several fake ones exist, which aim only to cause anxiety. Recipients of information are advised to cross-check first before spreading information received through social media and unofficial websites.

f. It is important to apply the situational crisis communication theory which was stated by Coombs because it will be helpful for institutions of disaster management in making appropriate, strategic and useful decisions. This would help in minimizing damage by formulating crisis response strategy guidelines, categorizing crisis types by crisis clusters, and formulating crisis response strategies. The three strategies will greatly assist institutions of disaster management in conveying information to the media. This is because how information about crises is framed in the media will determine how the public views the institution (Coombs, 2007; Kriyantono \& Mckenna, 2019).

\section{CONCLUSION}

ASEAN countries use the same disaster information media, namely, print and electronic media. Internet media, particularly social media, are the most widely used in conveying disaster information in ASEAN countries. Media modelling, such as simulations and disaster maps, is applied before a disaster to prepare appropriate measures. Early warning is provided during natural disasters by using sirens and flags, among others. All ASEAN countries have simulated modelling of disasters, particularly floods.

In Indonesia and Laos, print media (outdoor), such as sign systems, are also used to indicate the action and direction of evacuation in case of a disaster event. In Cambodia, billboards are used to convey information about the current flood height. In the Philippines, a disaster management museum and disaster libraries exist as media after disasters occur to inform people of the disasters that happened and to prepare for future disasters.

On the basis of the analysis results of the comparison of each component, most of the media used during a disaster are electronic, with a role in response to an ongoing disaster. One suggestion for future disaster information media is increasing usage of modelling to simulate disasters, including evacuation routes and rescue efforts, thereby providing education in disaster preparedness. Modelling is delivered long before a disaster occurs, and important for the institutional of disaster management to implement Situational crisis 
communication theory, thus it will be useful in reducing the loss of life and damage to infrastructure resulting from disaster events.

\section{ACKNOWLEDGEMENTS}

This research has been supported by grant code as usual ZG-2018-001 and Malaysia International Scholarship, the Institute of Visual Informatics-the National University of Malaysia and the Technical Implementation Unit-Information Technology Division, Indonesian Institute of Sciences.

\section{BIODATA}

Muhammad Yudhi Rezaldi, is a PhD Student at the Institute of Visual Informatics, Universiti Kebangsaan Malaysia (UKM). Email: rezaldi1106@gmail.com

Rabiah Abdul Kadir, is a Research Fellow at the Institute of Visual Informatics, Universiti Kebangsaan Malaysia (UKM). Email: rabiahivi@ukm.edu.my

Mohamad Taha ljab, is a research fellow at the Institute of Visual Informatics, Universiti Kebangsaan Malaysia (UKM). Email: taha@ukm.edu.my

Azlina Ahmad, is an Associate Professor at the Institute of Visual Informatics (IVI), Universiti Kebangsaan Malaysia (UKM). Email: azlinaivi@ukm.edu.my 


\section{REFERENCES}

$A B C$ International Development. (2017). Disaster Information providers in the Philippines. Australian Aid. Retrieved from http://www.abc.net.au/cm/lb/9223578/data/disaster-information-providers-inphilippines-data.pdf

Adila, I., Dewi, W. W. A., Tamitiadini, D., \& Syauki, W. R. (2017). Disaster mitigation action plan: Digital media on improving accountability and community relationships. IOP Conference Series: Earth and Environmental Science (Vol. 70, pp. 0-9). Surakarta, Indonesia. doi: 10.1088/1755-1315/70/1/012016

Ahmad, J., \& Lateh, H. (2016). Media and the environment in Malaysia: An analysis on news coverage of landslide disaster in Kuala Lumpur. Jurnal Komunikasi: Malaysian Journal of Communication, 32(2), 525-544.

Anson, S., Watson, H., Wadhwa, K., \& Metz, K. (2017). Analysing social media data for disaster preparedness: Understanding the opportunities and barriers faced by humanitarian actors. International Journal of Disaster Risk Reduction, 21, 131-139. doi: 10.1016/j.ijdrr.2016.11.014

Arifianto, S., \& Virhani, M. R. (2009). Disaster information and local culture (Case respondense flood in Bukit Duri village) / Informasi bencana dan budaya lokal (Kasus penganggulangan banjir di kelurahan Bukit Duri) (Artikel). Jakarta: Puslitbang Aptel SKDI Balitbang Sumber Daya Manusia Depkominfo.

Asian Disaster Preparedness Center. (2008). Program for hydro-meteorological disaster mitigation in secondary cities in Asia, flood disaster mitigation and river rehabilitation by Marikina City, Philippines. Retrieved on December 12, 2017, from http://www.unspider.org/sites/default/files/4-Flood_Mitigation_Philipines_ADPC.pdf

Aye,T. H., Zin, W. W., \& Maung, U. T. (2017). Development of flood inundation map for Bago River Basin. International Journal For Innovative Research in Multidisciplinary Field, 3(1), 1-6.

Baharudin, P. H. A. P., Au, T. W., \& Phon, A. S. (2017). A knowledge-based framework for mitigation hydro-meteorological disaster. Lecture Notes in Computer Science, 10387, 505-513.

Beggs, J. C. (2018). Applications: Disaster communication and community engagement. Journal Disaster Epidemiology, Chap. 14, 163-169.

Billa, L., Shattri, M., Mahmud, A. R., \& Ghazali, A. H. (2006). Comprehensive planning and the role of SDSS in flood disaster management in Malaysia. Disaster Prevention and Management: An International Journal, 15(2), 233-240.

Borton, J., \& Tho, C. (2017). Vietnam's social media shaping new environmentalism. Internews.com. Retrieved on December 12, 2017, from https: //www.internews.org/news/vietnams-social-media-shaping-new-environmentalism

Bourgoin, J., Castella, J.-C., Pullar, D., Lestrelin, G., \& Bouahom, B. (2012). Toward a land zoning negotiation support platform: "Tips and Trick" for participatory land use planning in Laos. Landscape and Urban Planning, 104(2), 270-278.

Brunai Darussalam Presentation. (2015). Community based disaster preparedness to support vulnerable people. The 13 th ASEAN \& Japan High Level Officials Meeting on Caring Societies 20 - 22 October 2015, Kobe, Japan. 
Burnett, W. C., Wattayakorn, G., Supcharoen, R., Sioudom, K., Kum, V., Chanyotha, S., \& Kritsananuwat, R. (2017). Groundwater discharge and phosphorus dynamics in a flood-pulse system: Tonle Sap Lake, Cambodia. Journal of Hydrology, 549, 79-91.

Callaghan, C. W. (2016). Disaster management, crowdsourced R\&D and probabilistic innovation theory: Toward real time disaster response capability. International Journal of Disaster Risk Reduction, 17, 238-250.

Cambodia Unicef. (2017). Publication: A girl reads a UNICEF leaflet about child rights, produced for Children's Day. Retrieved on December 11, 2017, from https://www.unicef.org/cambodia/results_for_children.html

Carley, K. M., Malik, M., Landwehr, P. M., Preffer, J., \& Huck, M. K. (2016). Crowd sourcing disaster management: The complex nature of Twitter usage in Padang Indonesia. Journal Safety Science, 90, 48-61.

Center for Excellence in Disaster Management \& Humanitarian Assistance. (2015). Thailand disaster management reference handbook (pp. 35-36). Hawaii: CFE. Retrieved on December 11, 2017, from https://reliefweb.int/report/thailand/disastermanagement-reference-handbook-2015-thailand

CFE-DMHA (Center for Excellence in Disaster Management \& Humanitarian Assistance). (2014). Cambodia disaster management reference handbook. Retrieve on December 15, 2017, from http://www.preventionweb.net/publications/view/44200

Cheng, J. W., Mitomo, H., Otsuka, T., \& Jeon, S. Y. (2015). The effects of ICT and mass media in post disaster recovery a two model case study of the great east Japan earthquake. Journal Telecommunications Policy, 39(6), 515-532.

Chan, E. S., Balmforth, D., Kan, Y. F., Koike, T., Lampe, L., \& Yong, K. Y., (2012). Report on key conclusions and recommendations of the expert panel on drainage design and flood protection measures. Retrieve on December 13, 2017, from https://www.pub.gov.sg/Documents/fullReport.pdf

Chong, T., Leong, C., Pan, S. L., Bahri, S., \& Fauzi, A. (2014). Use of social media in disaster relief during the Kuantan (Malaysia) flood. Thirty Fifth International Conference on Information Systems. Auckland: UMrepository.

Chongkolrattanaporn, T. (2013). Global warming campaigns, campaign effectiveness (PhD. Studies, Faculty of Arts, Macquarie University).

Coppola, D. P. (2011). The management of disasters. In, Introduction to International Disaster Management (2nd ed., pp. 1-35). UK: Butterworth-Heinemann.

Coombs, W. T. (2007). Protecting organization reputations during a crisis: The development and application of situational crisis communication theory. Corporate Reputation Review, 10(3), 163-176.

Disaster Recovery Framework. (2014). Lao PDR strengthening institutional capacities for resilient recovery. In, Disaster Recovery Framework Guide (pp. 10-11). Retrieve on December 12, 2017, from https://www.gfdrr.org/sites/default/files/publication/rcfs2014-laopdr.pdf

Disaster Risk Reduction in Lao PDR. (2016). Information kit for media. Retrieved on December 13, 2017, from https://www.adpc.net/igo/category/ID1021/doc/2016-pt37Na-ADPCInformation_Kit_for_Media_Lao_PDR.pdf

Dung, L. T. M. Y., Hai, V. M., Smyth, I., \& Harvey, C. (2012). Flood preparedness in Vietnam: A systematic gender-aware approach. Oxfam. Retrieve on December 13, 2017, from https://oxfamilibrary.openrepository.com/oxfam/bitstream/10546/247211/1/csflood-preparedness-vietnam-081012-en.pdf 
Dorasamy, M., Raman, M., Muthaiyah, S., \& Kaliannan, M. (2007). Disaster preparedness in Malaysia: An exploratory study. Proceeding paper of the 8th WSEAS International Conference On Management, Marketing and Finances (pp 19-30).

Ewart, J., McLean, H., \& Ames, K. (2016). Political communication and disasters: A four country analysis of how politicians should talk before, during and after disaster. Journal Discourse, Context \& Media, 11, 3-11.

Fernandez, G., \& Shaw, R. (2016). Urban Disaster and risk communication through youth organizations in the Philippines. Journal Urban Disasters and Resilience in Asia, 195207.

Goh, M. Y., Tan, S., \& Lai, K. C. (2015). Learning from the Bhopal disaster to improve process safety management in Singapore. Journal Process Safety and Environmental Protection, 97, 102-108.

Hamid, S., Bukhari, S., Ravana, S. D., Norman, A. A., \& ljab, M. T. (2016). Role of social media in information - Seeking behaviour of international student, a systematic literature review. Aslib Journal of Information Management, 68(5), 628-642.

Iqbal, M. J., Ali F. M., \& Khursheed, M. B. (2014). Analysis of role of media in disaster reporting in Pakistan. European Scientific Journal, 1, 570-575.

Jun, Y., \& Lihong, Y. (2017). The cloud technology double live data center information system research and design based on disaster recovery platform. Journal Procedia Engineering, 174, 1356-1370.

Kaewkitipong, L., Chen, C., \& Ractham, P. (2012). Lessons learned from the use of social media in combating a crisis, a case study of 2011 Thailand flooding disaster. Thirty Third International Conference on Information Systems, Project Management and IS Development, Orlando.

Keur, P. V. D., Bers, C. V., Henriksen, H. J., Nibanupudi, H. K., Yadav, S., \& Jaspers, F. (2016). Identification and analysis of uncertainty in disaster risk reduction and climate change adaptation in South and Southeast Asia. International Journal of Disaster Risk Reduction, 16, 208-214.

Kia, M. B., Pirasteh, S., Pradhan, B., Mahmud, A. R., Sulaiman, W. N. A., \& Moradi, A. (2012). An artificial neural network model for flood simulation using GIS: Johor River Basin, Malaysia. Journal Environmental Earth Sciences, 67(1), 251-264.

Kibanov, M., Stumme, G., Amin, I., \& Lee, J. G. (2017). Mining social media to inform Peatland fire and haze disaster management. Journal Social Network Analysis and Mining, 7(1), art no. 30.

Kim, J., \& Hastak, M. (2018). Social network analysis: Characteristics of online social network after a disaster. International Journal of Information Management, 38(1), 86-96.

Kitchenham, B., Brereton, O. P., Budgen, D., Turner, M., Bailey, J., \& Linkman, S. (2009). Systematic literature review in software engineering - A systemaatic literature review. Journal Information and Software Technology, 51, 7-15.

Kriyantono, R., \& Mckenna, B. (2019). Crisis response vs crisis cluster: A test of situational crisis communication theory on two crisis clusters in Indonesian public relation. Jurnal Komunikasi: Malaysian Journal of Communication, 35(1), 222-236.

Landwehr, P., Wei, W., Huck, M. K., \& Carley, K. M. (2016). Using Tweets to support disaster planning, warning and response. Journal Safety Science, 90, 33-47. 
Li, X., Wang, X., \& Babovic, V. (2018). Analysis of variability and trends of precipitation extremes in Singapore during 1980-2013. International Journal of Climatology, 38(1), 125-141.

Liu, Q., \& Wang, Q. (2018). A dynamic model of post disaster search and rescue considering information uncertainty. Lecture Notes in Electrical Engineering, 419, 597-606.

Linda,V. O. (2017). Disaster risk reduction and disaster management in Myanmar: The roles of employer and business membership organizations. Switzerland: International Labour Organization.

Lintner, B. (2003). Burma, Laos, and Cambodia, status of media. Journal Encyclopedia of International Media and Communications, 1, 139-152.

Matthews, J. (2017). The role of a local newspaper after disaster: An intrinsic case study of Ishinomaki, Japan. Asian Journal of Communication, 27(5), 464-479.

Mekong River Commission. (2011). The flood management and mitigation programme 20112015. Retrieved from on December 9, 2017, from http://www.mrcmekong.org/assets/Publications/Programme-Documents/FMMP2011-2015-Programme-Document-Volume-1-file-date-21042011.pdf

Minear, L., Colin, S., \& Thomas, W. (2003). The news media and humanitarian action (pp. 4452). Lexington, Kentucky: The National Emergency Management Association.

Miranda, E. (2002). An evaluation of the paired comparisons method for software sizing. The 2000 International Conference on Software Engineering (ICSE) (pp. 597-604). Limerick: IEEE.

National Disaster Risk Reduction and Management Plan (NDRRMP) 2011-2028. (2012), Retrieved on December 13, 2017, from http://www.adrc.asia/documents/dm_information/Philippines_NDRRM_Plan_20112028.pdf

Ndah, A. B., \& Odihi, J. O. (2017). A systematic study of disaster risk in Brunei Darussalam and options for vulnerability - based disaster risk reduction. International Journal of Disaster Risk Science, 8(2), 208-223.

NNDMCR (National Natural Disaster management Committee Republic of The Union of Myanmar. (2015). Myanmar flood response 2015. Retrieved on December 11, 2017, from http://themimu.info/sites/themimu.info/files/documents/Situation_Report_No.4_N NDMC_02Sep2015.pdf

Nugroho, S. P. (2017). Social media \& crowd source disaster monitoring system: Lessons learned from Jakarta's flood. Paper presented at GeoSmart Asia, Kuala Lumpur, 24 August 2017.

Nunung, P. (2008). Disaster, information and media involvement/bencana, informasi dan keterlibatan media. Journal of Social and Political Sciences, 11(8), 287-306.

Ock, M. D. M., Nari, Y. M. P. H., Jeonghoon, A. H. N., \& Woo, J. M. (2016). How many alternetives can be ranked? A comparison of the paired comparison and rangking methods. Journal Value in Health, 19, 655-660.

Parwanto, N. B., \& Oyama, T. (2014). A statistical analysis and comparison of historical earthquake and tsunami disaster in Japan Indonesia. International Journal of Disaster Risk Reduction, 7, 122-141.

Plate, E. J. (2007). Early warning and flood forecasting for large river with the lower mekong as example. Journal of Hydro Environment Research, 1(2), 80-94. 
Ragini, J. r., Anand, P. M. R., \& Bhaskar, V. ( 2017). Mining crisis information: A strategic approach for detection of people at risk through social media analysis. International Journal of Disaster Risk Reduction, 27, 556-566.

Rezaldi, M. Y., Kadir, R. A., Ijab, M. T., \& Ahmad, A. (2017). Review of spatial and non-spatial data transformation to 3D geovisualization for natural disaster. Proceeding paper of 5th International Visual Informatics Conference (pp. 340-351).

Rural Settings. (2011). Guidance on mainstreaming disaster risk reduction in the education sector. Retrieved on December 10, 2017, from http://www.adpc.net/2011/Category/Documents/DocumentDB/Guidance_MDRD_E du_Myamar_EN.pdf

Sayama, T., Tatebe, Y., \& Tanaka, S. (2017). An emergency response-type rainfall-runoffinundation simulation for 2011 Thailand floods. Journal Flood Risk Management, 10(1), 65-78.

Silvestri, N. (2017). Building emergency public information structure for response: Lessons learned from New York City. Journal of Business Continuity \& Emergency Planning, 10(2), 132-140.

Sun, S., Merolla, A. J., Seo, M., \& Zhang, S. (2013). Self-construal and natural disaster coverage: How self perception influences psychological intrusion and concern for other. Asian Journal of Communication, 23(1), 17-37.

Takagi, H., Esteban, M., \& Tran, T. T. (2014). Coastal Vulnerabilities in a fast growing Vietnamese city (pp. 157-171). London: Elsevier.

Tan, W. K., Teh, S. Y., \& Koh, H.L. (2017). Tsunami run-up and inundation along the coast of Sabah and Serawak, Malaysia due to a potential Brunei submarine mass failure. Journal Environmental Science and Pollution Research, 24(19), 15976-15994.

Texier, P. (2008). Floods in Jakarta: When the extreme reveals daily structural constraints and mismanagement. Disaster Prevention and Management: An International Journal, 17(3), 358-372.

Thanh, V. Q., Reyns, J., Wackerman, C., Eidam, F. F., \& Roelvink, D. (2017). Modelling suspended sediment dynamics on the subaqueous delta of the Mekong River. Journal Continental Shelf Research, 147, 213-230.

Tsukida, K., \& Gupta, M. R. (2011). How to analyze paired comparison data (1st ed.). Washington: Department of Electrical Engineering University of Washington. Retrieved on December 10, 2017, from http://mayagupta.org/publications/PairedComparisonTutorialTSukidaGupta.pdf

Tuan, T. H., \& Bui, T. D. (2012). Natural disasters in Vietnam a synthesis from a socioeconomic perpective. In, The ekonomic impac of natural disaster (pp. 179-198). New York: Oxford University Press.

Venter, D. (2016), The role of the media in the implementation of disaster management ( $p p$ 1-16). Retrieved on December 11, 2017, from http://www.disaster.co.za/pics/PrDavidVenterDMISAConf1999Media.pdf

Vieweg, S., Castillo, C., \& Imran, M. (2014). Integrating social media communications into the rapid assessment of sudden onset disasters (pp. 444-461). 6th International Conference, Barcelona, Springer.

Westgard, J. O. (2009). The comparison of methods experiment. Westgard QC. Retrieved on December 113, 2017, from https://www.westgard.com/ 
Worboys, L., Lockwood, M., Kothari, A., Feary, S., \& Pulsford, I. (2015). The media and protected area. Sydney: ANU Press.

Xu, J., Wang, Z., Shen, F., Quyang, C., \& Tu, Y. (2016). Natural disaster and social conflict: Systematic literature review. International Journal of Disaster Risk Reduction, 17, 3848.

Zhang, N., Huang, H., \& Su, B. (2016). Comprehensive analysis of information dissemination in disasters. Physica A: Statistical Mechanics and Its Applications, 662(15), 846-857.

Zhou, L., Wu, X., Xu, Z., \& Fujita, H. (2018). Emergency dicision making for natural disaster: An Overview. International Journal of Disaster Risk Reduction, 27, 567-576.

Zin, W. W., Kawasaki, A., \& Win, S. (2015). River flood inundation mapping in the Bago River Basin, Myanmar. Hydrological Research Letters, 9(4), 97-102. 